\title{
Garcinone $C$ exerts antitumor activity by modulating the expression of ATR/Stat3/4E-BP1 in nasopharyngeal carcinoma cells
}

\author{
YUDUI XIA ${ }^{1,2,5^{*}}$, XIA LIU ${ }^{1,2^{*}}$, CHUNLIN ZOU ${ }^{1,2}$, SHIXIU FENG ${ }^{3}$, HONGWEI GUO $^{1,2}$, \\ YEGUO YANG $^{1,2}$, YONG LEI ${ }^{1,2}$, JIAN ZHANG ${ }^{1,2,4}$ and YI LU ${ }^{1,2}$
}

${ }^{1}$ Key Laboratory of Longevity and Ageing-Related Diseases, Ministry of Education; ${ }^{2}$ Center for Translational Medicine, Guangxi Medical University, Nanning, Guangxi 530021; ${ }^{3}$ Key Laboratory of Southern Subtropical Plant Diversity, Shenzhen Fairy Lake Botanical Garden, Chinese Academy of Sciences, Shenzhen, Guangdong 518004, P.R. China;

${ }^{4}$ Department of Urology and Pathology, School of Medicine, University of Michigan, Ann Arbor, MI 48109, USA; ${ }^{5}$ Xinxiang Central Hospital of Henan, Xinxiang, Henan 453000, P.R. China

Received July 23, 2017; Accepted December 4, 2017

DOI: $10.3892 /$ or.2018.6218

\begin{abstract}
Nasopharyngeal carcinoma (NPC) is one of the most common head and neck malignancies and is typically treated with radiotherapy and chemotherapy. Garcinone C, a natural compound isolated from Garcinia oblongifolia Champ., is a xanthone derivative with potential cytotoxic effects on certain cancers. However, there are limited studies regarding its effects on NPC cells, and its mechanism of action in NPC remains unknown. In the present study, we found that garcinone $\mathrm{C}$ significantly inhibited cell viability of the human NPC cell lines CNE1, CNE2, HK1 and HONE1. This inhibition was exerted in a time- and dose-dependent manner. Flow cytometry demonstrated that garcinone $\mathrm{C}$ arrested the cell cycle at the $\mathrm{S}$ phase. Moreover, with $10 \mu \mathrm{M}$ of high-dose garcinone $\mathrm{C}$ treatment, the cells exhibited necrotic morphology changes including cell swelling, rough endoplasmic reticulum degranulation, endoplasmic reticulum dilatation, mitochondrial swelling and vacuolar degeneration. In addition, we found that garcinone $\mathrm{C}$ stimulated the expression levels of ATR and 4E-BP1, while efficiently inhibiting the expression levels of cyclin B1, cyclin D1, cyclin E2, cdc2, CDK7 and Stat3. Collectively, the ability of garcinone C to inhibit NPC in growth in vitro suggested that garcinone $\mathrm{C}$ may be a novel agent for the management of NPC.
\end{abstract}

Correspondence to: Professor Jian Zhang or Professor Yi Lu, Center for Translational Medicine, Guangxi Medical University, 22 Shuangyong Road, Nanning, Guangxi 530021, P.R. China

E-mail: jianzhang008@hotmail.com

E-mail: luyi5555@hotmail.com

*Contributed equally

Key words: garcinone C, nasopharyngeal carcinoma, cell cycle, organelles, natural compound

\section{Introduction}

Malignancies remain a major challenge to global public health (1). One of the most common head and neck malignancies worldwide, especially in southern China, Southeast Asia, and North Africa, is nasopharyngeal carcinoma (NPC) (2). There are three subtypes of NPC, classified by the World Health Organization, that include squamous cell carcinoma, non-keratinizing carcinoma and undifferentiated carcinoma (3).

Radiotherapy is the standard treatment for early-stage NPC, but chemotherapy is also very important in the standard treatment of locally advanced and metastatic NPC. The common chemotherapies used to treat NPC are cisplatin, carboplatin, 5-fluorouracil, gemcitabine, paclitaxel, anthracyclines, bleomycin, epirubicin and cetuximab (2). However, one of the major obstacles in successfully treating advanced NPC is the development of drug resistance, which can result from a variety of factors, including increased DNA damage tolerance (4). Because of this major obstacle that drug resistance poses, new and better treatment options for NPC are urgently needed.

In the last few decades, natural compounds have gained increasing attention as a source of potential anticancer agents. Xanthones are oxygen-containing heterocyclic compounds widely distributed in various plants and microorganisms. It is well known that xanthones have remarkable pharmacological effects, such as anticancer, antioxidant, anti-inflammatory, antidiabetic, antimicrobial, antithrombotic and hepatoprotective activities (5-7). Among them, the anticancer potential of xanthones has drawn an increasing amount of attention. For example, some xanthones, such as gambogic acid (8-12) and $\alpha$-mangostin (13-16), have been shown to exhibit anticancer properties, including antiproliferation, antiangiogenesis and antimetastasis.

Garcinone $\mathrm{C}\left(\mathrm{C}_{23} \mathrm{H}_{26} \mathrm{O}_{7}\right.$, $\mathrm{MW} 414.5$, Fig. 1), a xanthone derivative, is a natural compound extracted from Garcinia oblongifolia Champ. (a traditional Chinese medicine) that is used as an anti-inflammatory, analgesia, astringency and 
granulation-promoting medicine. Recently, it was reported that garcinone $\mathrm{C}$ exhibits cytotoxicity against MCF-7, A549, Hep-G2 and CNE human cancer cell lines in vitro (17). However, the function and molecular mechanism of this compound in cell growth and cell cycle progression have not been yet elucidated. In the present study, CNE1 (well-differentiated squamous cell carcinoma), CNE2 (non-keratinizing carcinoma), HK1 (well-differentiated squamous cell carcinoma) and HONE1 (undifferentiated carcinoma) NPC cells were treated with different concentrations of garcinone $\mathrm{C}$ and then subjected to biochemical, microscopic, flow cytometric, and molecular analyses to determine the efficacy and mechanism of action of garcinone $\mathrm{C}$ in NPC.

\section{Materials and methods}

Plant material. The bark of Garcinia oblongifolia Champ was collected from Wuzhishan, Hainan, China in October 2013 and identified by Dr Xilong Zheng, an expert from the Crops Research Institute, Guangdong Academy of Agricultural Sciences, Guangzhou, China. A voucher specimen was deposited in the South China Botanical Garden, Chinese Academy of Sciences, Guangzhou, China.

Extraction, isolation, and identification of garcinone $C$. The air-dried bark $(10.0 \mathrm{~kg})$ was powdered and extracted three times with $90 \%$ ethanol for $48 \mathrm{~h}$ per extraction. The extract was concentrated under vacuum, suspended in 50\% ethanol, and then successively partitioned with petroleum ether, EtOAc. The EtOAc soluble extract (320.0 g) was subjected to silica gel column chromatography (100-200 mesh) and eluted with a gradient solvent system of $\mathrm{CCl}_{3}-\mathrm{MeOH}$ (from 90:10 to 70:30) to yield 10 sub-fractions, A-J. Sub-fraction $\mathrm{E}$ was re-subjected to silica gel column chromatography $\left(\mathrm{CCl}_{3}-\mathrm{MeOH}-\mathrm{H}_{2} \mathrm{O}, 100: 11: 2\right)$ and then purified by Sephadex LH-20 column chromatography eluted with methanol to yield garcinone $\mathrm{C}(28 \mathrm{mg})$.

The physiochemical characteristics of garcinone $\mathrm{C}$ were identified by electron spray ionization mass spectrometry, ${ }^{1} \mathrm{H}$ and ${ }^{13} \mathrm{C}$ nuclear magnetic resonance (NMR) spectra. Garcinone $\mathrm{C}\left(\mathrm{C}_{23} \mathrm{H}_{26} \mathrm{O}_{7}\right)$ (Fig. 1): yellow needles, $>98.0 \%$ purity. ESIMS $(\mathrm{m} / \mathrm{z}): 415[\mathrm{M}+\mathrm{H}]^{+}, 437[\mathrm{M}+\mathrm{Na}]^{+}, 413[\mathrm{M}-\mathrm{H}]^{-}$. ${ }^{1} \mathrm{H}-\mathrm{NMR}\left(500 \mathrm{MHz},\left(\mathrm{CD}_{3}\right)_{2} \mathrm{CO}-d_{6}\right)$ : $\delta 13.92$ (s, OH-1), $1.65(3 \mathrm{H}$, s, H-14), 1.32 (6H, d, H-19, 20), 1.79 (3H, s, H-15), 1.94-1.82 $(2 \mathrm{H}, \mathrm{m}, \mathrm{H}-17), 3.35(2 \mathrm{H}, \mathrm{d}, J=7.2 \mathrm{~Hz}, \mathrm{H}-11), 3.58-3.43(2 \mathrm{H}, \mathrm{m}$, $\mathrm{H}-16), 5.29(1 \mathrm{H}, \mathrm{t}, J=7.2 \mathrm{~Hz}, \mathrm{H}-12), 6.39(1 \mathrm{H}, \mathrm{s}, \mathrm{H}-4), 6.79(1 \mathrm{H}$, s, H-5). ${ }^{13} \mathrm{C}-\mathrm{NMR}\left(125 \mathrm{MHz},\left(\mathrm{CD}_{3}\right)_{2} \mathrm{CO}-d_{6}\right)$ : $\delta 161.2(\mathrm{C}-1), 110.7$ (C-2), 162.7 (C-3), 92.9 (C-4), 155.8 (C-4a), 101.0 (C-5), 153.9 (C-6), 141.3 (C-7), 131.0 (C-8), 111.8 (C-8a), 183.0 (C-9), 103.6 (C-9a), 153.2 (C-10a), 21.9 (C-11), 123.5 (C-12), 131.3 (C-13), 25.8 (C-14), 17.8 (C-15), 22.5 (C-16), 44.1 (C-17), 71.1 (C-18). Garcinone $\mathrm{C}$ was dissolved in dimethylsulfoxide (DMSO) to prepare $20 \mathrm{mM}$ garcinone $\mathrm{C}$ stock solution.

Cell culture. Human NPC cell lines CNE1, CNE2, HK1, and HONE1 were a kind gift of Dr Chao-Nan Qian (Department of Nasopharyngeal Carcinoma, Sun Yat-sen University Cancer Center, Guangzhou, China). Cells were cultured at $37^{\circ} \mathrm{C}$, in a humidified atmosphere with $5 \% \mathrm{CO}_{2}$, in Dulbecco's modified Eagle's medium supplemented with $10 \%$ fetal bovine serum (FBS), $1 \%$ L-glutamine, $100 \mathrm{U} / \mathrm{ml}$ penicillin, $100 \mu \mathrm{g} / \mathrm{ml}$ of

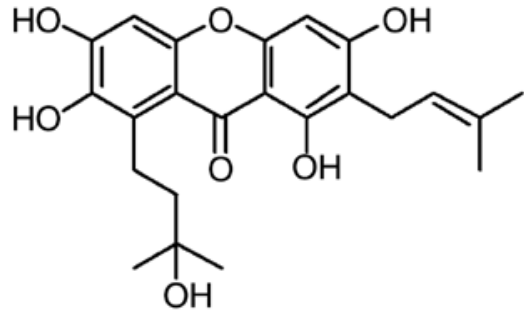

Figure 1. The basic chemical structure of garcinone $\mathrm{C}$ extracted from the bark of Garcinia oblongifolia Champ.

streptomycin and $0.25 \mu \mathrm{g} / \mathrm{ml}$ of Fungizone ${ }^{\circledR}$ (Gibco; Thermo Fisher Scientific, Inc., Waltham, MA, USA). The cells were harvested by trypsinization and plated $24 \mathrm{~h}$ before treatment with garcinone $\mathrm{C}$ or paclitaxel.

MTS assay for cell viability. CNE1, CNE2, HK1 and HONE1 cells were plated in 96-well plates and $24 \mathrm{~h}$ later, they were treated with $1.25,1.875,2.5,3.75,5,7.5,10,15$ and $20 \mu \mathrm{M}$ of garcinone $\mathrm{C}$ or $1 / 1,000$ DMSO for 24,48 and $72 \mathrm{~h}$. As a positive control, CNE1 and HONE1 cells were treated with or without paclitaxel for 24, 48 and $72 \mathrm{~h}$. Cell viability was measured using Promega's CellTiter $96 \mathrm{AQ}_{\text {ueous }}$ One Solution Cell Proliferation Assay (Promega, Madison, WI, USA) and read using a Multiskan GO Microplate spectrophotometer (Thermo Fisher Scientific) at $490 \mathrm{~nm}$. The cell viability ratio was calculated according to the following equation: cell viability $(\%)=$ treated group/control group $\mathrm{x} 100 \%$. The half-maximal inhibitory concentration $\left(\mathrm{IC}_{50}\right)$ was calculated using the Bliss method. The results were estimated from the data of six technical replicates and three biological replicates.

Colony formation assay. Cells were diluted and seeded at 500 cells per well in 6-well plates. The following day, CNE1 and HK1 cells were treated with 0.625 and $0.9375 \mu \mathrm{M}$ garcinone $\mathrm{C}$ or DMSO, and CNE2 and HONE1 cells were treated with 1.25 and $2.5 \mu \mathrm{M}$ garcinone $\mathrm{C}$ or DMSO. Medium was replaced with fresh medium containing garcinone $\mathrm{C}$ every 4 days. After incubation for 10 days, colonies were fixed with $4 \%$ paraformaldehyde for $20 \mathrm{~min}$, visualized with crystal violet, and then scanned with Canon CanoScan 9000F Color Image Scanner. Visible colonies were counted. Colony formation rate $(\%)=$ number of colonies/number of seeded cells $\times 100 \%$.

Flow cytometry analysis of apoptosis. CNE1 and CNE2 cells were seeded in $25-\mathrm{cm}^{2}$ flasks and treated with 5, 7.5 and $10 \mu \mathrm{M}$ of garcinone $\mathrm{C}$ or $1 / 2,000$ dimethyl sulfoxide (DMSO) for 24, 48 and $72 \mathrm{~h}$. Harvested cells were washed with Dulbecco's phosphate-buffered saline (DPBS) and stained with Annexin V and propidium iodide (PI), according to the instructions of the FITC Annexin V Apoptosis Detection kit I (BD Biosciences, San Diego, CA, USA). Apoptotic cells were quantified by BD Accuri C6 Flow Cytometer (BD Biosciences). Stained cell populations were defined as: lower left quadrant, living cells (Annexin $\mathrm{V}^{-} / \mathrm{PI}$ ); upper left quadrant, primary necrotic cells (Annexin $\mathrm{V}^{-} / \mathrm{PI}^{+}$); lower right quadrant, early apoptotic cells (Annexin $\left.\mathrm{V}^{+} / \mathrm{PI}\right)$; upper right quadrant, late apoptotic cells $\left(\right.$ Annexin $\left.\mathrm{V}^{+} / \mathrm{PI}^{+}\right)$. Approximately 50,000 events were collected per sample. 
A
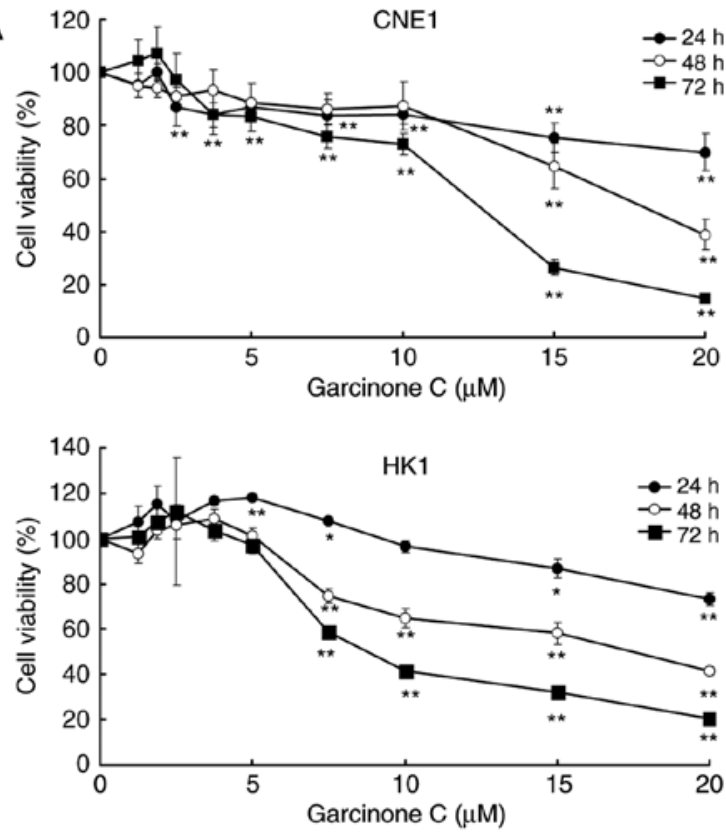

B

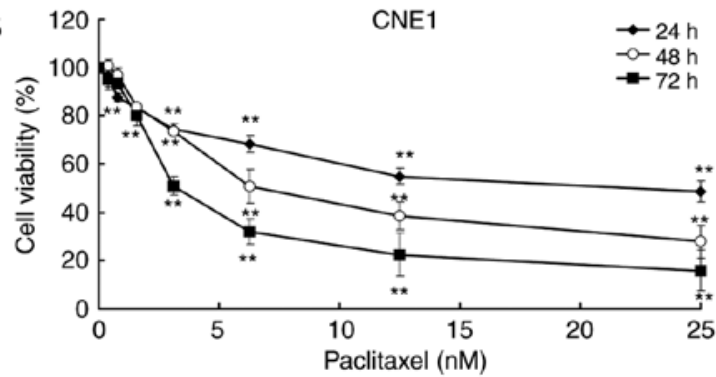

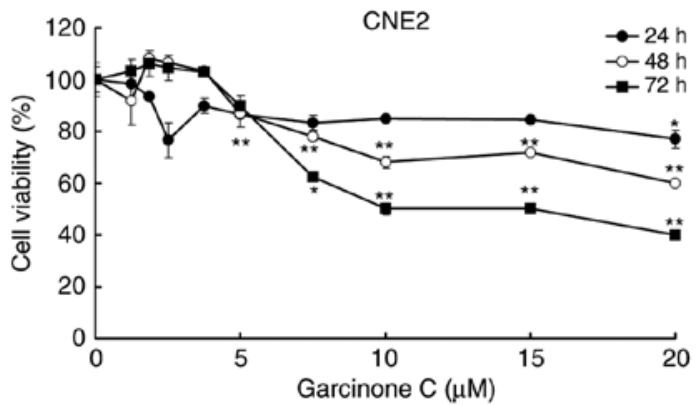
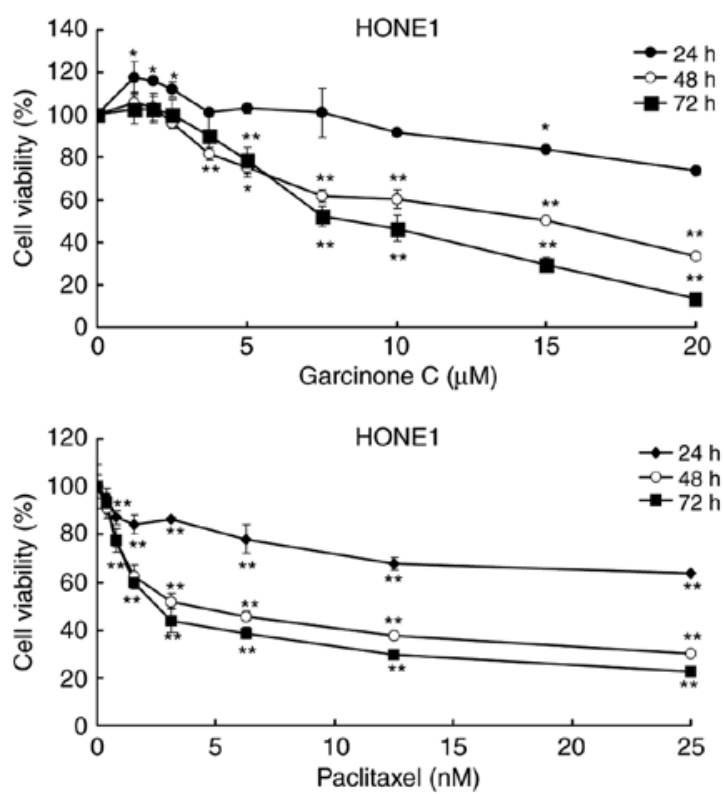

Figure 2. Time- and dose-dependent effects of garcinone $\mathrm{C}$ on the viability of CNE1, CNE2, HK1 and HONE1 cells. Cells were treated with garcinone C (A), or paclitaxel (B) for 24, 48, and $72 \mathrm{~h}$. Cell viability was measured by MTS assay. The y-axis represents the cell viability ratio relative to DMSO-treated cells. Data are expressed as mean $\pm \mathrm{SD}$ of three experiments. ${ }^{*} \mathrm{P}<0.05$ and ${ }^{* *} \mathrm{P}<0.01$ compared with the control.

Apoptotic cell percentage $=$ [upper right quadrant (UR) + lower right quadrant (LR)] \%.

Cell cycle analysis. CNE1, CNE2, HK1 and HONE1 cells were treated with $5,7.5$ and $10 \mu \mathrm{M}$ of garcinone $\mathrm{C}$ or $1 / 2,000$ DMSO for 24, 48 and $72 \mathrm{~h}$. Harvested cells were washed with DPBS and stained with PI according to the protocol of the Cycletest $^{\mathrm{TM}}$ Plus DNA Reagent kit (BD Biosciences). Cell cycle distribution was analyzed using the BD Accuri C6 flow cytometer. Approximately 30,000 events were collected per sample. The results were further analyzed using ModFit LT software (Verity Software House Inc., Topsham, ME, USA).

Transmission electron microscopy (TEM). To investigate and study the cell damage caused by garcinone C, CNE1 and HONE1 cells were respectively cultured with $10 \mu \mathrm{M}$ garcinone $\mathrm{C}$ or DMSO for 24, 48 and $72 \mathrm{~h}$. After washing with DPBS, the cells were fixed with $1 \mathrm{ml}$ of $3 \%$ glutaraldehyde and stored at $4^{\circ} \mathrm{C}$. Cells were then washed three times with phosphate-buffered saline (PBS) and further postfixed with $1 \%$ osmium tetroxide for 1-2 h. After rinsing three times with PBS, the cells were dehydrated in a graded series of 50,70 and 90\% ethanol and then $90 \%$ ethanol:90\% acetone (1:1), 90\% acetone, and three times with $100 \%$ acetone. After dehydration, the cells were embedded in epoxy resin 618 for sectioning. Ultrathin sections were obtained using a Leica EM UC7 ultramicrotome (Leica Microsystems, Buffalo Grove, IL, USA). After staining with uranyl acetate and lead citrate, the sections were examined and photographed with a Hitachi H-7650 transmission electron microscope (Hitachi, Tokyo, Japan).

Protein isolation and western blot analysis. Cells were treated with 5, 7.5 and $10 \mu \mathrm{M}$ of garcinone $\mathrm{C}$ for 24,48 and $72 \mathrm{~h}$. Cell lysates were prepared in RIPA lysis buffer supplemented with a protease inhibitor cocktail, Phenylmethylsulfonyl fluoride, and Phosphatase Inhibitors Cocktail 2 and 3, and then stored at $4^{\circ} \mathrm{C}$ overnight. Total lysates were centrifuged for $20 \mathrm{~min}$, at $13,523 \times \mathrm{g}$ at $4^{\circ} \mathrm{C}$, and the supernatant was collected and stored at $-80^{\circ} \mathrm{C}$. The quantitative analysis of protein was determined using the Pierce BCA Protein Assay Reagent Kit (Thermo Fisher Scientific, Rockford, IL, USA) and $50 \mu \mathrm{g}$ of protein was used for SDS-PAGE electrophoresis. Antibodies against cyclin B1 (\#4138), cyclin D1 (\#2926), cyclin E2 (\#4132), cdc2 (\#9112), CDK7 (\#2916), GAPDH (\#2118), Atg3 (\#3415), AKT (\#9272), Stat5 (\#9358), Stat3 (\#9139), 4E-BP1 (\#9644),

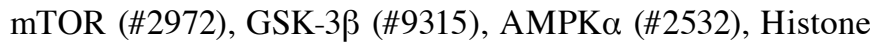
H2B (\#12364), anti-rabbit IgG (\#7074), and anti-mouse IgG (\#7076) were purchased from Cell Signaling Technology, Inc. (Beverly, MA, USA). Anti-DNA PKcs [Y393] (ab32566) and anti-ATR antibodies (ab10312) were purchased from Abcam 


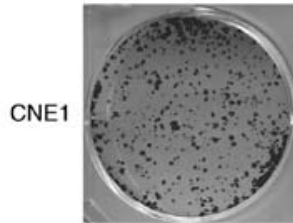

Control

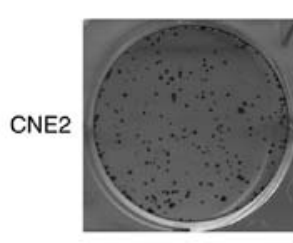

Control

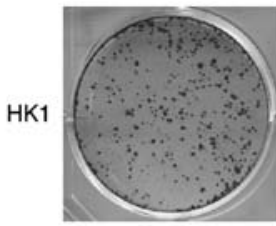

Control

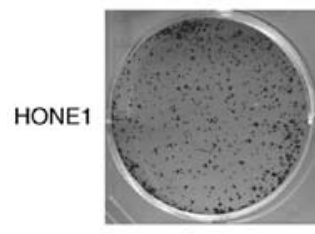

Control

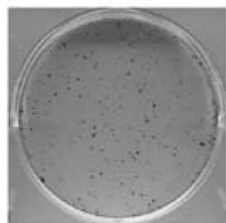

$0.625 \mu \mathrm{M}$

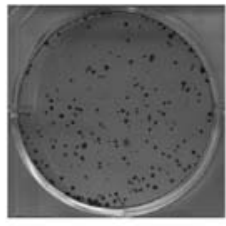

$1.25 \mu \mathrm{M}$

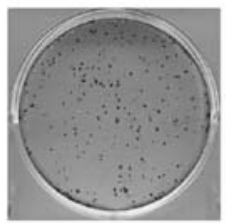

$0.625 \mu \mathrm{M}$

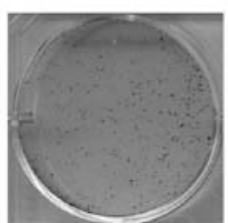

$1.25 \mu \mathrm{M}$

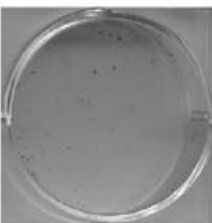

$0.9375 \mu \mathrm{M}$

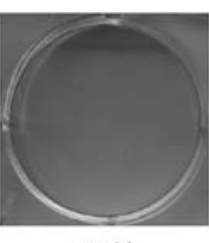

$5 \mu \mathrm{M}$

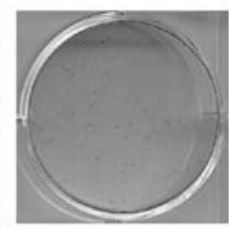

$0.9375 \mu \mathrm{M}$

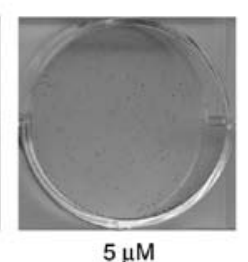

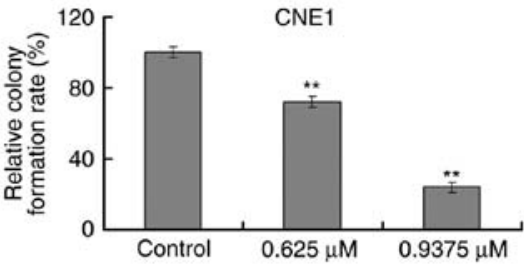
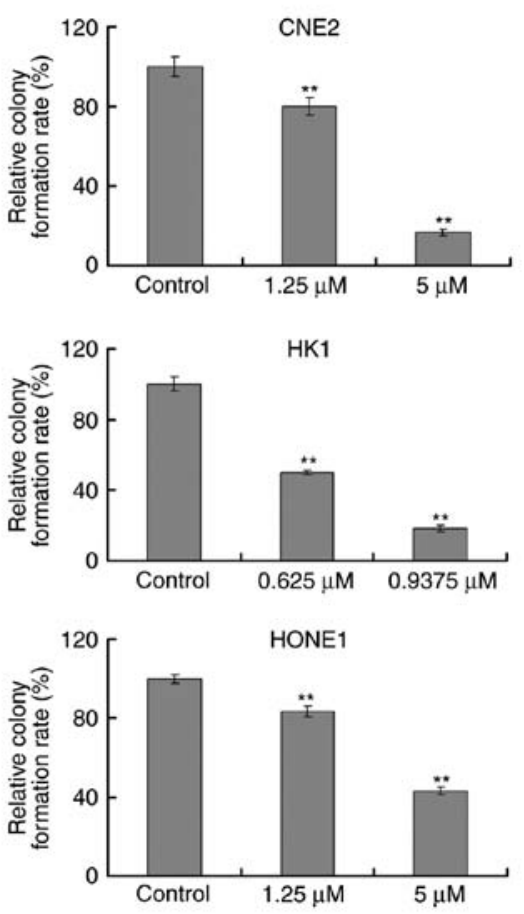

Figure 3. Suppressive effect of garcinone C on the colony-formation ability of NPC cells. Left panel, representative images of the colony formation assay. Right panel, analysis of relative colony formation rates of $\mathrm{CNE} 1, \mathrm{CNE} 2, \mathrm{HK} 1$, and HONE1 cells. Data are mean $\pm \mathrm{SD}$ of three independent experiments. ${ }^{* *} \mathrm{P}<0.01$ relative to the control.

(Cambridge, MA, USA). GAPDH was used as an equal loading control. Thermo Scientific Pierce ECL Western Blotting Substrate (Rockford, IL, USA) and Kodak X-OMAT BT Film (Kodak, Rochester, NY, USA) were used to detect the bound immune complexes. The films were then developed by a Kodak X-OMAT 2000 Processor and scanned with a Canon CanoScan 9000F Color Image Scanner (Canon, Melville, NY, USA).

Statistical analysis. All experiments were repeated at least three times. Statistical significance of the differences between two samples was evaluated by the unpaired two-tailed Student's t-test. Significance was established at ${ }^{*} \mathrm{P}<0.05$ or ${ }^{* *} \mathrm{P}<0.01$. Statistical significance of the differences among samples was assessed by one-way analysis of variance followed by the least significant difference and Student-Neumann-Keuls post hoc comparison. The analyses were performed with SPSS 13.0 software (SPSS Inc., Chicago, IL, USA). The threshold of significance was defined as $\mathrm{P}<0.05$.

\section{Results}

Garcinone $C$ inhibits the cell viability of human NPC cells in a time-and dose-dependent manner. To investigate the effect of garcinone $\mathrm{C}$ on the viability of the human NPC cell lines CNE1, CNE2, HK1 and HONE1, the cells were treated with garcinone $\mathrm{C}$ at a concentration ranging from 0 to $20 \mu \mathrm{M}$ for
24, 48 and $72 \mathrm{~h}$. After exposure to garcinone C, cell viability was determined using an MTS assay. The results showed that garcinone $\mathrm{C}$ treatment inhibited cell viability in these four cell lines in a time- and dose-dependent manner (Fig. 2). The $\mathrm{IC}_{50}$ value of garcinone $\mathrm{C}$ after $72 \mathrm{~h}$ of incubation was $10.68 \pm 0.89$, $13.24 \pm 0.20,9.71 \pm 1.34$ and $8.99 \pm 1.15 \mu \mathrm{M}$ for CNE1, CNE2, HK1 and HONE1 cells, respectively. Paclitaxel, an antitumor drug that is known to inhibit cell viability, was used as a positive control for the MTS assay. As shown in Fig. 2, paclitaxel robustly inhibited cell viability in the CNE1 and HONE1 cells, in a time- and dose-dependent manner, with a $72 \mathrm{~h} \mathrm{IC}_{50}$ of $5.72 \pm 1.43$ and $3.5 \pm 0.80 \mathrm{nM}$.

Garcinone $C$ reduces the colony-formation ability of human NPC cells. To further demonstrate the anticancer effects of garcinone $\mathrm{C}$, the colony formation ability of NPC cells after treatment with garcinone $\mathrm{C}$ was assessed. $\mathrm{CNE} 1$ and $\mathrm{HK} 1$ cells were treated with 0.625 or $0.9375 \mu \mathrm{M}$ of garcinone $\mathrm{C}$ for 10 days, while CNE2 and HONE1 cells were treated with 1.25 or $5 \mu \mathrm{M}$ of garcinone $\mathrm{C}$ for 10 days. The results demonstrated that garcinone $\mathrm{C}$ significantly delayed the ability of NPC cells to form colonies $(\mathrm{P}<0.01)$, in a dose-dependent manner (Fig. 3).

Garcinone C slightly induces the apoptosis of NPC cells. Having found that garcinone $C$ caused inhibition of cell growth, we investigated whether this was due to the induction 
A

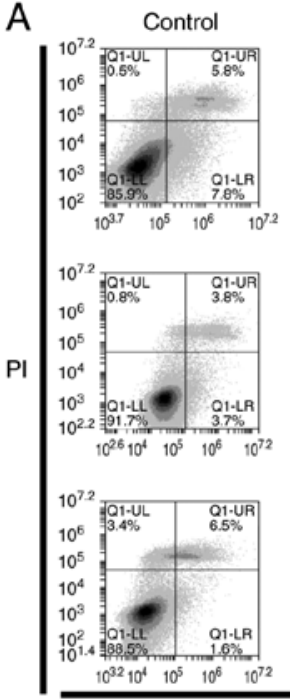

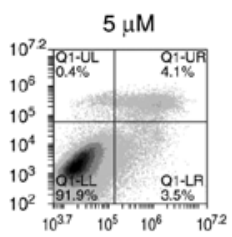
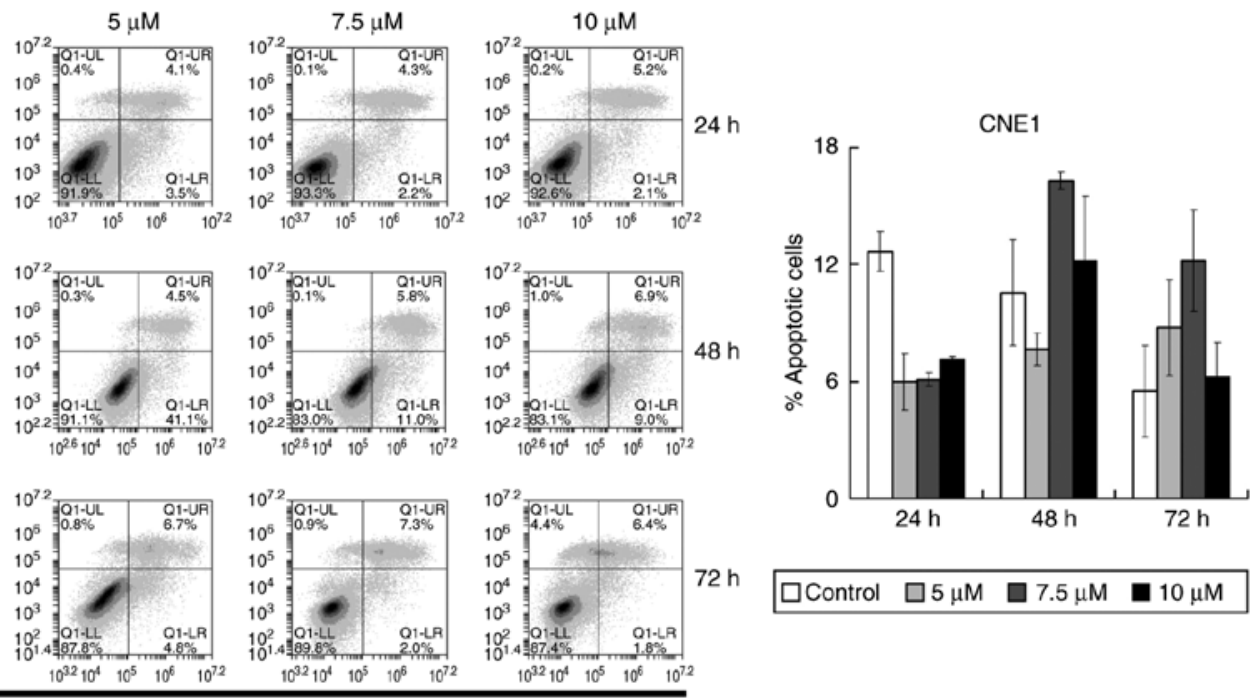

B
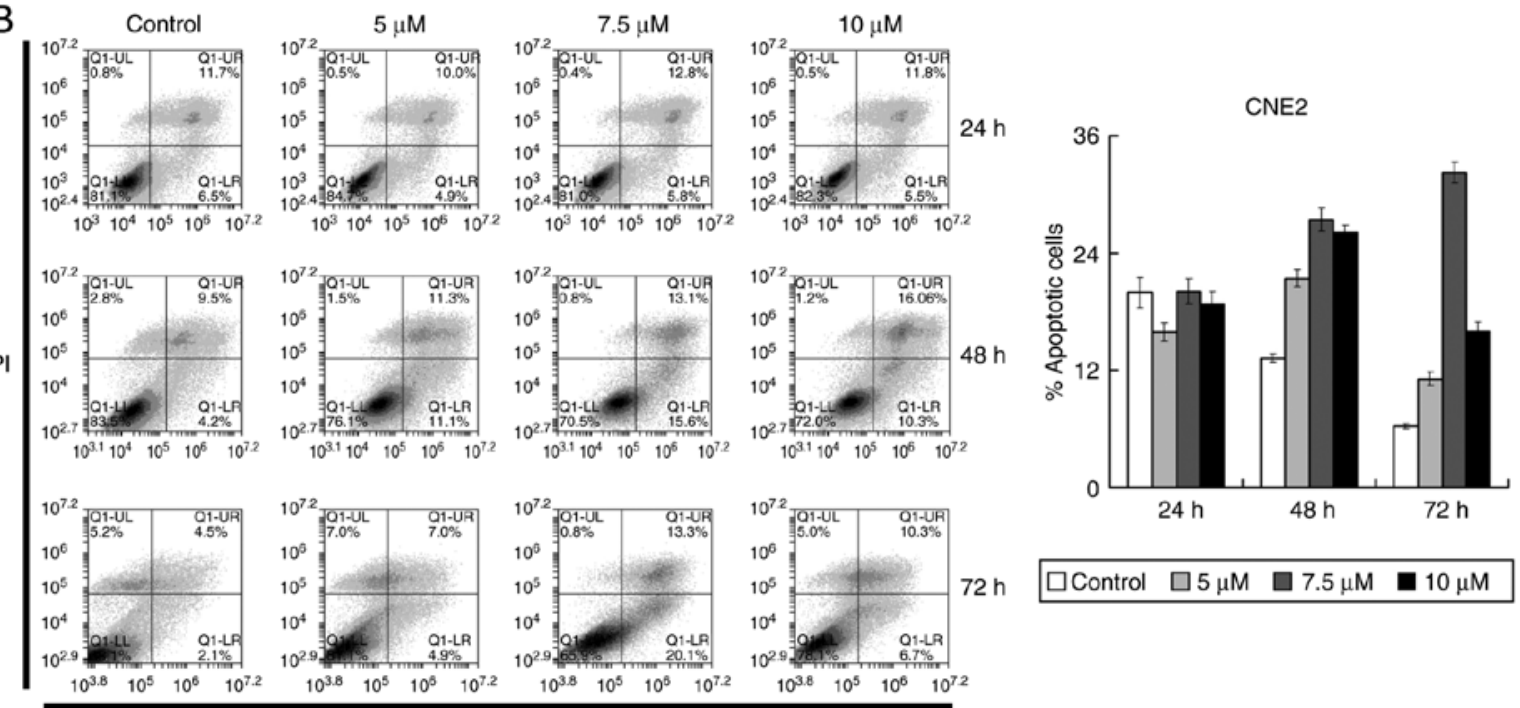

Annexin V

Figure 4. Induction of apoptosis by garcinone C. After 24, 48, and $72 \mathrm{~h}$ of incubation with garcinone C at the indicated concentrations, CNE1 and CNE2 cells were stained with Annexin V and PI, and then analyzed by flow cytometry. (A) Flow cytometric analysis of apoptosis in the CNE1 cells; (B) flow cytometric analysis of apoptosis in the CNE2 cells. Apoptotic cell percentage $=$ [upper right quadrant $(\mathrm{UR})+$ lower right quadrant $(\mathrm{LR})] \%$.

of apoptosis in the CNE1 and CNE2 cells. Cells were treated with $5,7.5$ and $10 \mu \mathrm{M}$ of garcinone C or DMSO (control) for 24, 48 and $72 \mathrm{~h}$. Subsequently, the cells were stained with Annexin V and PI, and subjected to flow cytometry to quantify the amount of apoptotic cells. The results revealed that garcinone $\mathrm{C}$ caused a slight increase in the apoptotic cell population in CNE1 and CNE2 cells (Fig. 4). However, the modest increase in the number of apoptotic cells after garcinone $\mathrm{C}$ treatment suggest that apoptosis may not be the major reason for the cell growth inhibition.

Garcinone $C$ induces $S$ phase cell cycle arrest. To assess whether garcinone $\mathrm{C}$ induces cell growth inhibition via alterations in cell cycle progression, we evaluated the effect of garcinone $\mathrm{C}$ on the cell cycle. As shown in Fig. 5, there was a significant decrease in the proportion of cells in the $G_{0} / G_{1}$ phase, and a significant increase in the proportion of cells in the $\mathrm{S}$ phase after cells were treated with garcinone $\mathrm{C}$, vs. the control. For example (Fig. 5B), the majority of control-treated
CNE2 cells were in the $\mathrm{G}_{0} / \mathrm{G}_{1}$ phase $(53.38 \pm 0.55 \%)$, with a $\mathrm{G}_{2} / \mathrm{M}$-phase fraction of $18.45 \pm 0.38 \%$, and the remaining control cells $(28.17 \pm 0.93 \%)$ were found to be in the $S$ phase. However, garcinone $\mathrm{C}$ treatment produced a shift in the DNA content histogram. The $\mathrm{G}_{0} / \mathrm{G}_{1}$ phase fraction decreased significantly to $47.23 \pm 0.93 \%$ after $24 \mathrm{~h}$ of $10 \mu \mathrm{M}$ garcinone $\mathrm{C}$ treatment, $14.33 \pm 0.25 \%$ after $48 \mathrm{~h}$ of $10 \mu \mathrm{M}$ garcinone $\mathrm{C}$ treatment, and $4.03 \pm 0.08 \%$ after $72 \mathrm{~h}$ of $10 \mu \mathrm{M}$ garcinone $\mathrm{C}$ treatment. The decrease in the $\mathrm{G}_{0} / \mathrm{G}_{1}$-phase fraction was offset by a rise in the S-phase fraction, which increased from $28.17 \pm 0.93$ to $42.99 \pm 0.88 \%$ after $24 \mathrm{~h}$ of treatment, $71.47 \pm 0.45 \%$ after $48 \mathrm{~h}$ of treatment, and $71.73 \pm 0.15 \%$ after $72 \mathrm{~h}$ of treatment. These results indicated that garcinone $\mathrm{C}$ efficiently inhibited the cell division by arresting cells in the $\mathrm{S}$ phase, suggesting that the inhibition of NPC cell proliferation by garcinone $\mathrm{C}$ is the result of cell cycle blockade.

High-dose garcinone $C$ induces cell necrosis in a time-dependent manner. Next, we examined cells for 


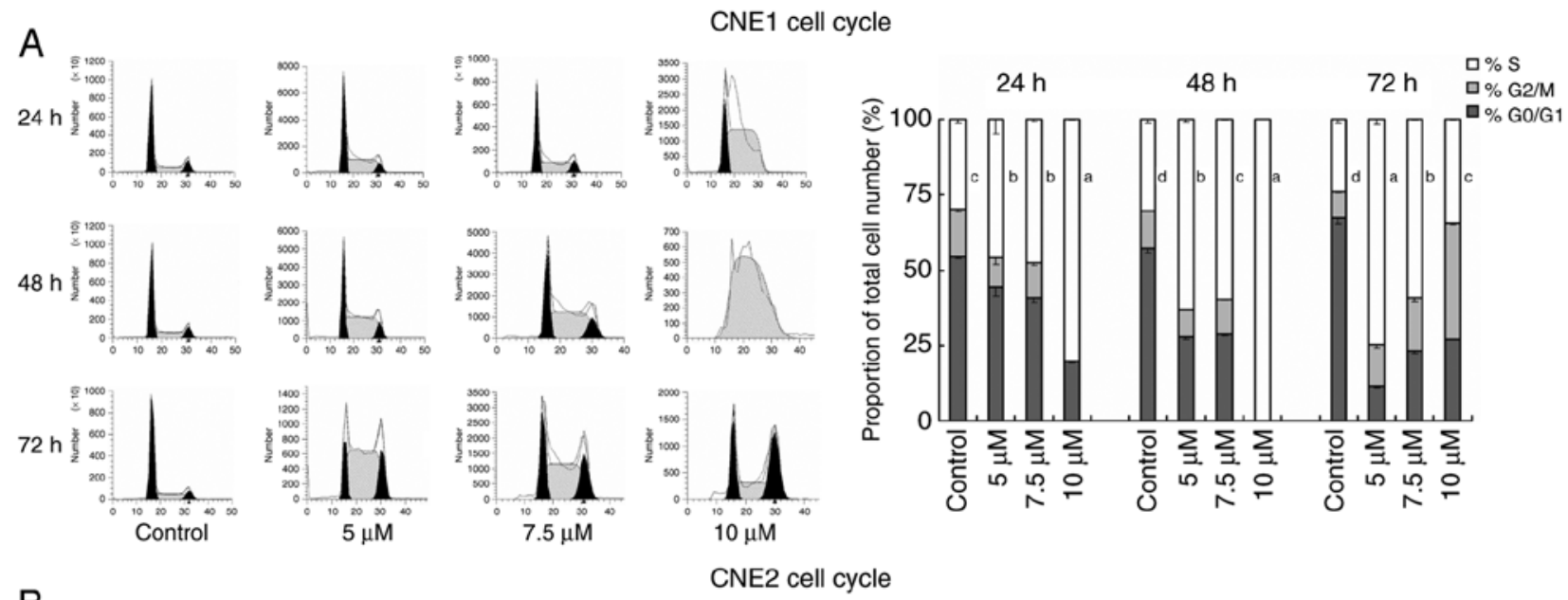

\section{B}

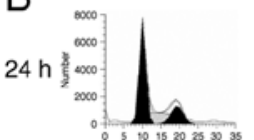

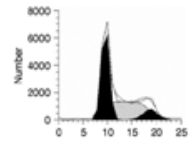

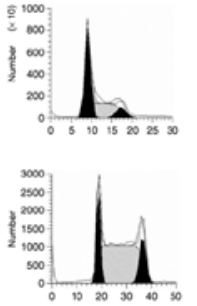<smiles>C#CC(C)=CC</smiles>

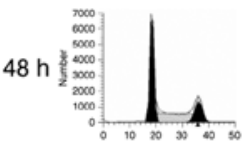

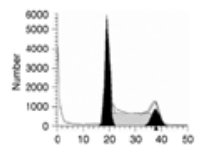

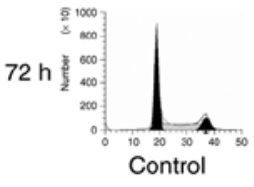
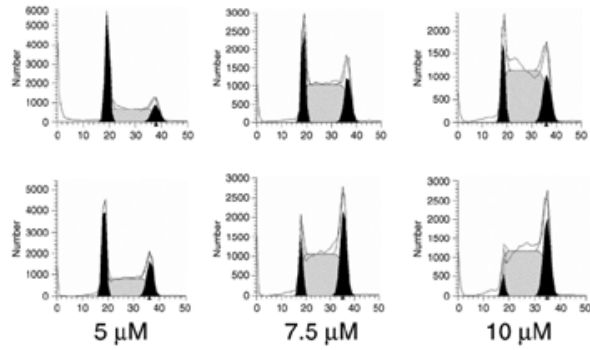

C
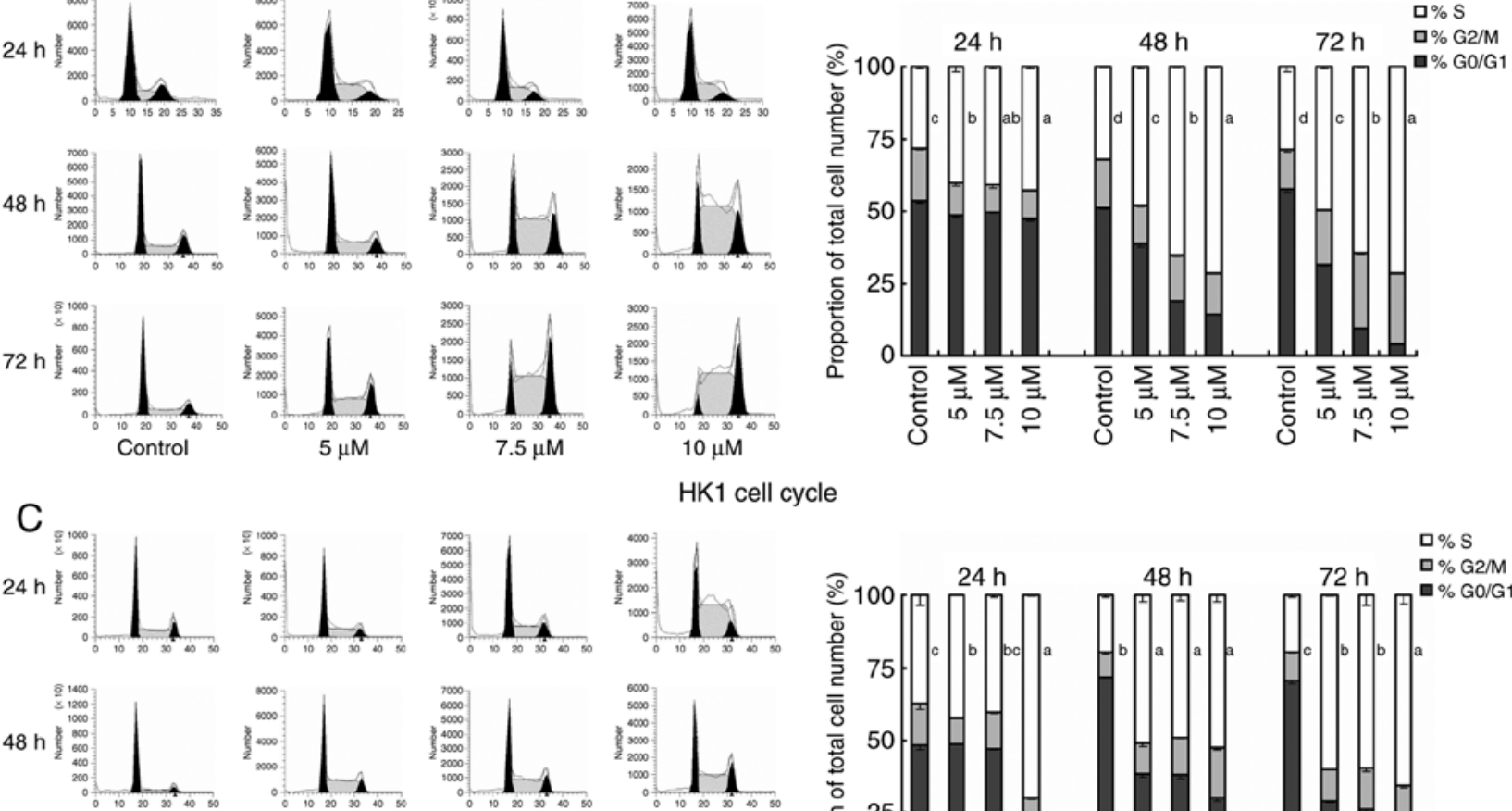

HK1 cell cycle
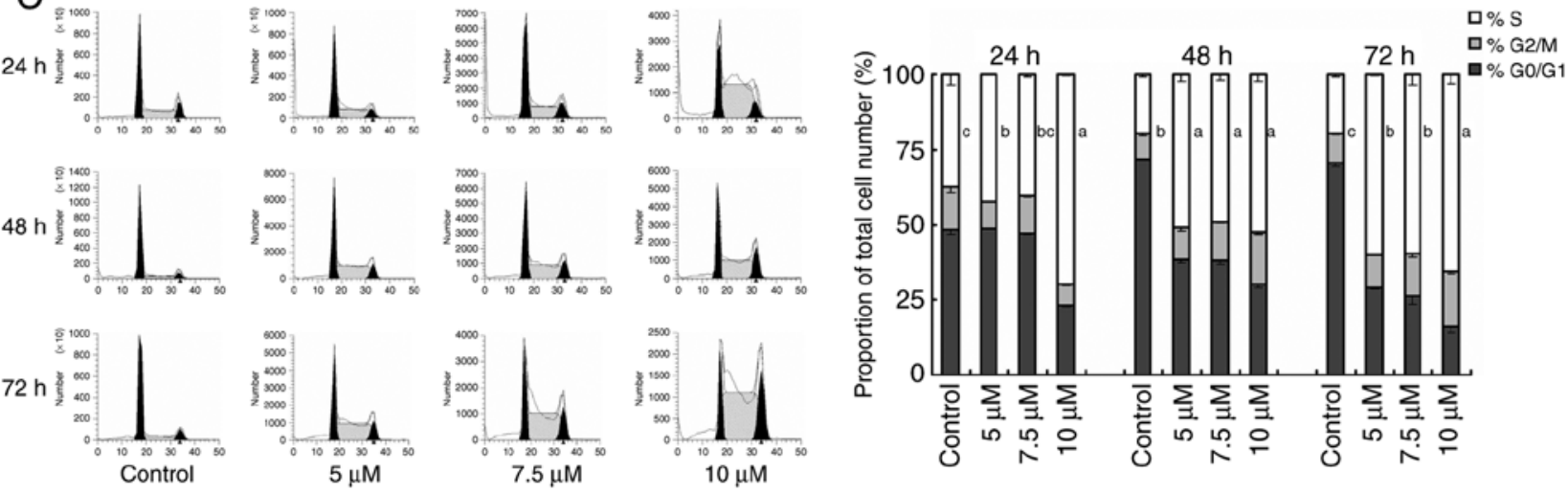

HONE1 cell cycle
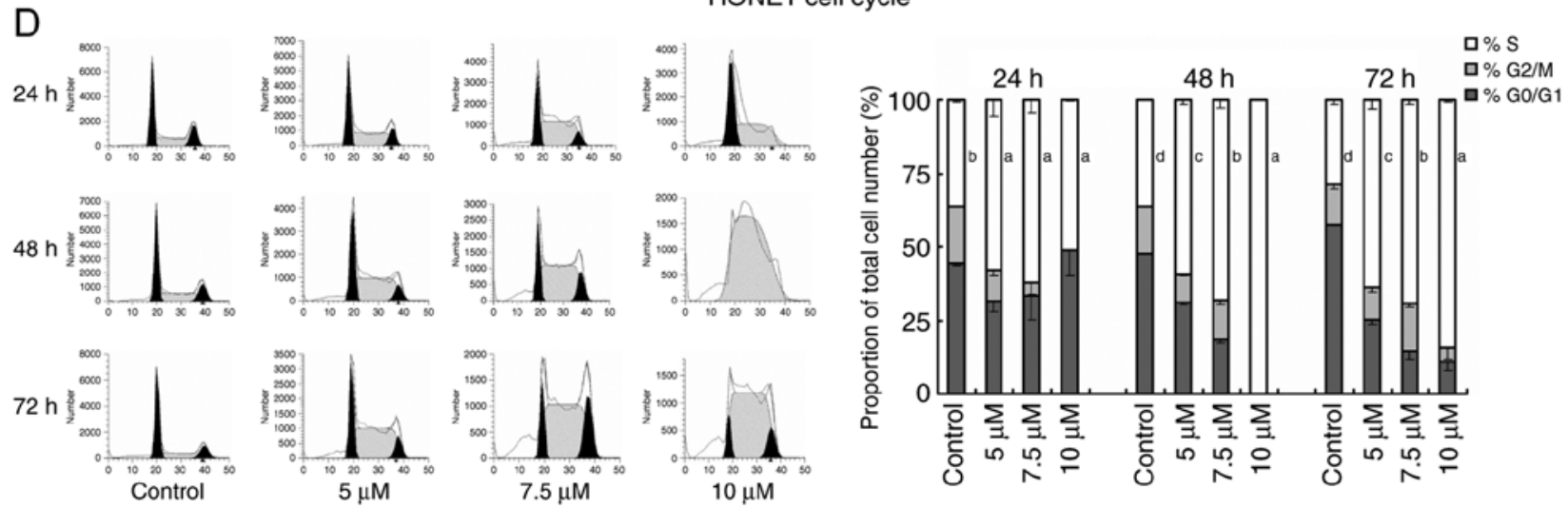

Figure 5. Induction of CNE1, CNE2, HK1, and HONE1 cell cycle arrest by garcinone C. The population distribution of four cell lines was assessed by cell cycle

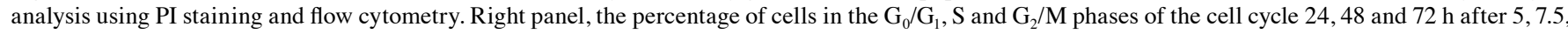
and $10 \mu \mathrm{M}$ garcinone $\mathrm{C}$ treatment $(\mathrm{n}=3$; error bars represent mean $\pm \mathrm{SD}$; a different letter on the right of the $\mathrm{S}$ phase column indicates a significant difference between different concentrations of garcinone $\mathrm{C} ; \mathrm{P}<0.05$, one-way analysis of variance, and least significant difference/Student-Neumann-Keuls post hoc test). Left panel, representative flow cytometry profiles from three independent experiments for each condition. 


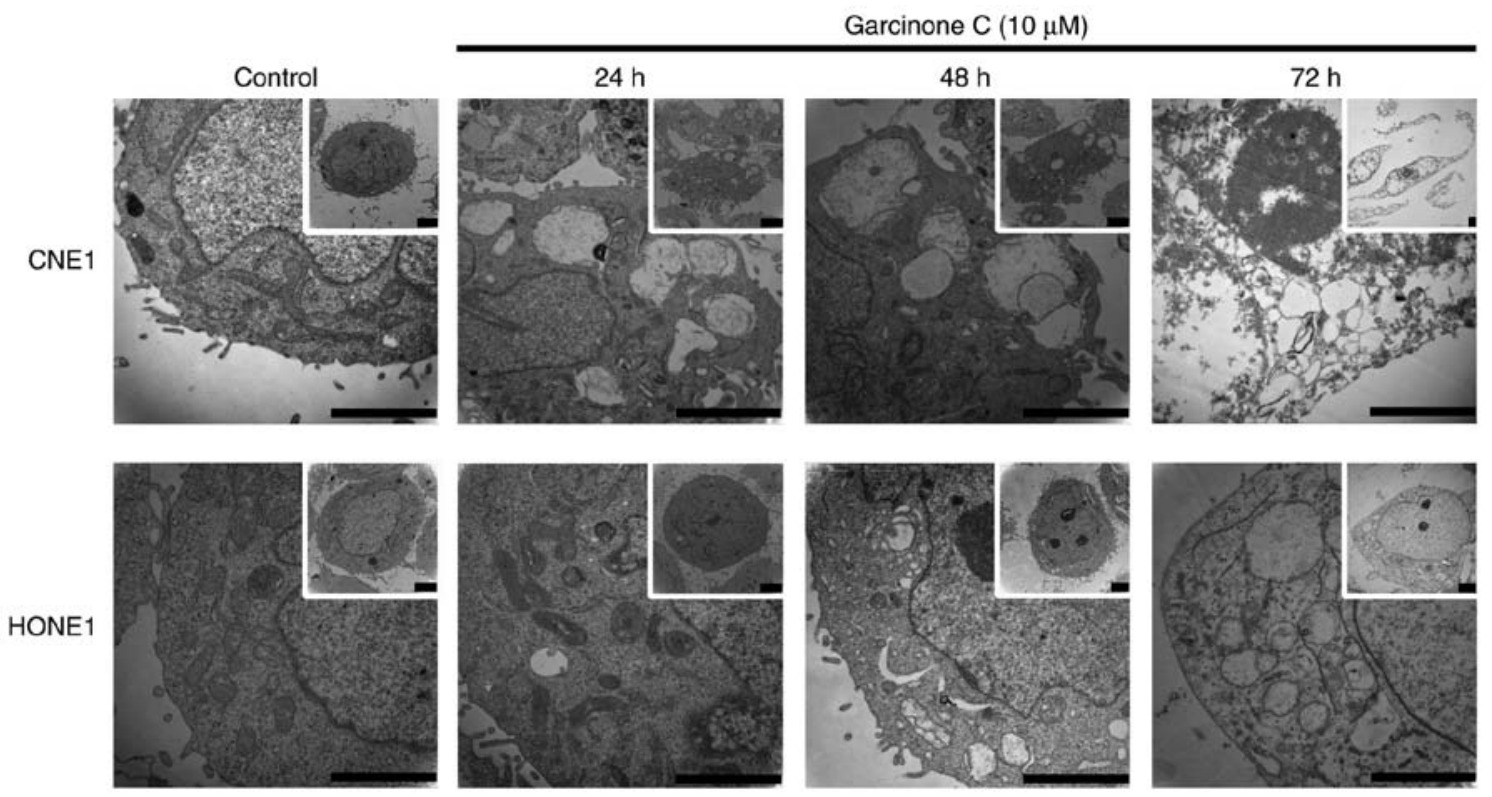

Figure 6. Ultrastructural features of DMSO-treated CNE1 and HONE1 cells or garcinone C (10 $\mu \mathrm{M})$-treated cells examined by TEM (x25,000). Microvilli are present on the surface of CNE1 and HONE1 cells. The cytoplasm contains abundant mitochondria and ribosomes. After garcinone $\mathrm{C}$ treatment, mitochondrial swelling, vacuolization, degranulation of rough endoplasmic reticulum and dilatation of the endoplasmic reticulum were observed. Scale bar=2 $\mu \mathrm{m}$.

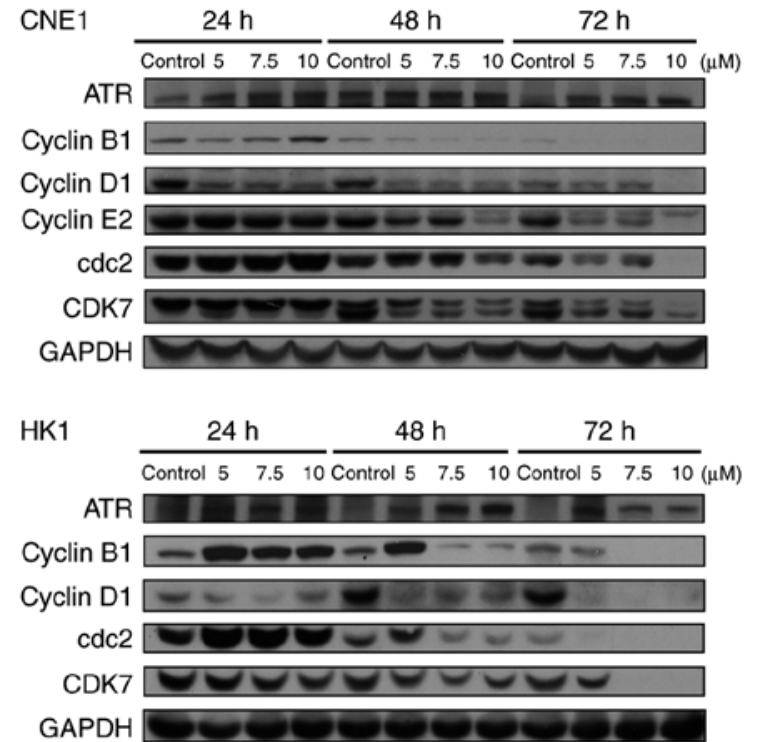

CNE2 $\frac{24 \mathrm{~h}}{\text { Control } 5 \quad 7.5} \frac{48 \mathrm{~h}}{\text { Control } 5 \quad 7.5} \frac{70 \mathrm{~h}}{\text { Control } 5 \quad 7.5 \quad 10}(\mu \mathrm{M})$
Cyclin B1
Cyclin D1
Cyclin E2
cdc2
CDK7
GAPDH

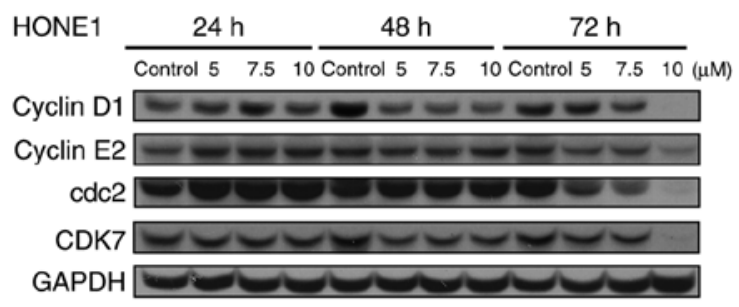

Figure 7. Effect of garcinone $\mathrm{C}$ on cell cycle-related proteins in CNE1, CNE2, HK1, and HONE1 cells. Total cell lysates were prepared and subjected to SDS-PAGE followed by western blot analysis. Membranes were probed with anti-ATR, cyclin B1, cyclin D1, cyclin E2, cdc2, CDK7 and GAPDH. GAPDH was used as a loading control. The experiment was repeated three times with similar results.

ultrastructural differences using TEM. As shown in Fig. 6, DMSO-treated control CNE1 and HONE1 cells exhibited normal morphology, with microvilli on the cell surface, abundant mitochondria and ribosomes. Upon exposure to $10 \mu \mathrm{M}$ of garcinone $\mathrm{C}$, cells exhibited a time-dependent increase in necrotic morphology, including cell swelling, rough endoplasmic reticulum degranulation, endoplasmic reticulum dilatation, mitochondrial swelling, vacuolar degeneration and loss of microvilli.

Garcinone C affects the expression levels of cell cycle-related proteins. Having noted that garcinone $\mathrm{C}$ induces cell cycle arrest in NPC cells, we investigated whether garcinone C could regulate the expression levels of cell cycle-related proteins. In agreement, a decrease in cyclin B1, cyclin D1, cyclin E2, cdc2 and CDK7 expression was observed in a dose- and time-dependent manner after treatments of 5, 7.5 and $10 \mu \mathrm{M}$ garcinone $\mathrm{C}$ for 24,48 and $72 \mathrm{~h}$ in CNE1, CNE2, HK1 and HONE1 cells (Fig. 7). Additionally, an increase in ataxia telangiectasia and Rad3 related protein (ATR) expression was observed in CNE1 and HK1 cells. Together, our data indicated that garcinone $\mathrm{C}$ induced cell cycle arrest via the downregulation of cyclin B1, cyclin D1, cyclin E2, cdc2 and CDK7, presumably through ATR activation. 


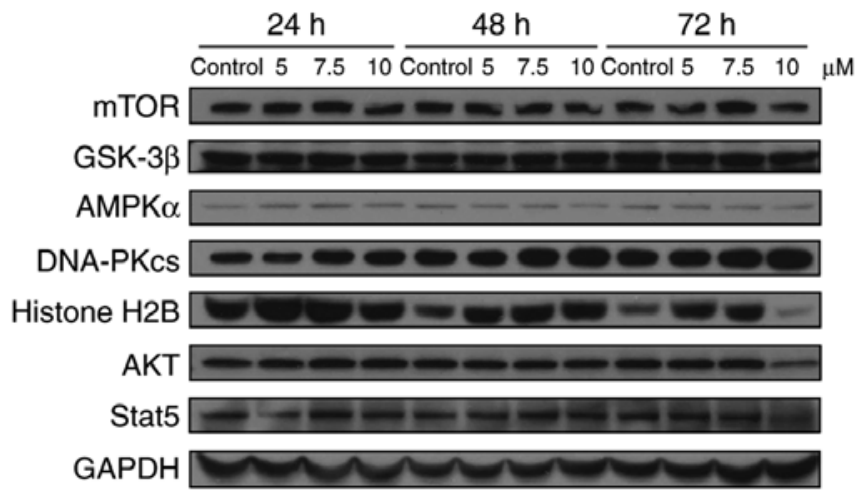

Figure 8. Western blot analysis showed that the expression levels of mTOR, GSK-3 $\beta$, AMPK $\alpha$, DNA-PKcs, Histone H2B, AKT and Stat5 were not affected by garcinone $\mathrm{C}$ in CNE1 cells. CNE1 cells were treated with 5, 7.5 and $10 \mu \mathrm{M}$ of garcinone $\mathrm{C}$ or 1/2,000 DMSO (control) for 24,48 and $72 \mathrm{~h}$ Cells were lysed and total protein was collected for western blot analysis.

Garcinone $C$ decreases the expression level of Stat3 and increases the expression level of $4 E-B P 1$. To further evaluate the molecular mechanisms involved in the anticancer activity of garcinone $\mathrm{C}$, we assessed the involvement of several key signal transduction pathways implicated in tumor progression by western blot analysis. As shown in Fig. 8, our results showed that treatment of CNE1 cells with garcinone $\mathrm{C}$ did not significantly affect the protein levels of mTOR, GSK-3 $\beta$, AMPK $\alpha$, DNA-dependent protein kinase, catalytic subunit (DNA-PKcs), Histone H2B, AKT, or Stat5 in a time- or dose-dependent manner. However, we noted a decrease in the levels of Stat 3 and an increase in the levels of 4E-BP1 in the four NPC cell lines treated with garcinone C (Fig. 9).

\section{Discussion}

In the present study, we demonstrated that garcinone $\mathrm{C}$ significantly inhibited the cell proliferation and colony-formation ability of NPC cells in vitro, in a dose- and time-dependent manner. Mechanistically, the inhibitory effect of garcinone $\mathrm{C}$ on cell growth could be ascribed to the arrest of the cell cycle in the $\mathrm{S}$ phase.

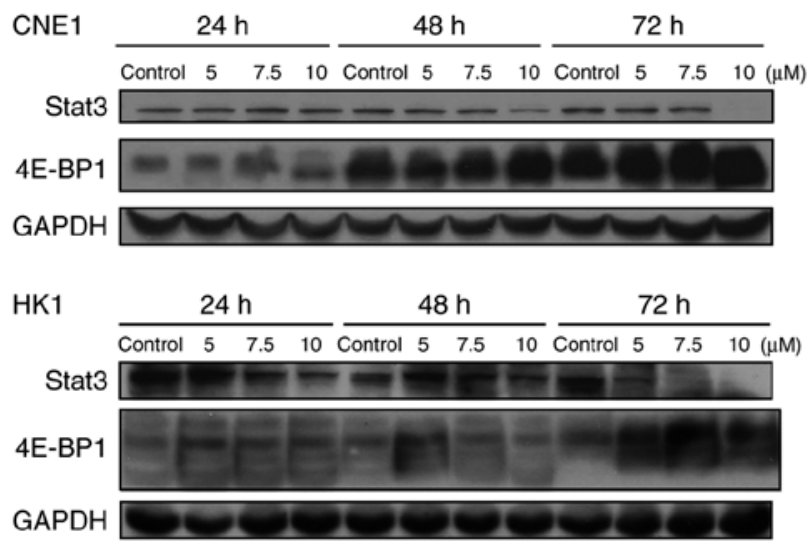

DNA damage checkpoints play an important role in normal nasopharyngeal epithelial cells by protecting them from genome instability and tumorigenesis. In NPC, targeting activation of the DNA damage checkpoint is a major therapeutic strategy (18). Moreover, increased DNA damage tolerance is one of the reasons for the development of drug resistance (19). In this study, we detected the expression levels of DNA damage-related proteins, ATR and DNA-PKcs after treatments with garcinone $C$. The results revealed that garcinone $C$ induced the expression level of ATR, but did not effect the expression level of DNA-PKcs. ATR is a phosphatidylinositol 3 kinase-related kinase (PIKK) family member that is activated in response to sensing DNA damage/replication blocks and triggers the DNA damage checkpoint, leading to the arrest of cell cycle progression (20). Although cell growth and cell cycle inhibition are complex processes, which involve many pathways, activation of the DNA damage checkpoint by ATR accumulation could be one of the mechanisms responsible for the ability of garcinone $\mathrm{C}$ to inhibit cell growth and induce cell cycle arrest. Therefore, garcinone $\mathrm{C}$ might be a new compound for targeting the DNA damage checkpoint in NPC cells and could be a novel drug candidate to use in combination with other agents to enhance the antitumor activity of other chemotherapies.

Cells die through two main processes: necrosis, defined as cell death due to unexpected and accidental cell damage, or apoptosis. In this study, tumor cell necrosis, morphologically characterized by a gain in cell volume, swelling of organelles, and subsequent loss of intracellular contents, was detected within $72 \mathrm{~h}$ of $10 \mu \mathrm{M}$ high-dose garcinone $\mathrm{C}$ treatment. However, the presence of necrosis can only indicate that a cell has died, but not necessarily how death occurred (21). Moreover, necrotic pathways are poorly defined and require further elucidation. Therefore, our data indicate that garcinone C-induced NPC cell necrosis is associated with S phase cell cycle arrest, but further investigation is required.

The signal transducer and activator of transcription (Stat) family, including Stat1-6, regulates many aspects of cell growth, survival and differentiation. In particular, Stat 3 is constitutively activated in many different types of cancer, plays a pivotal role in tumor growth, and possesses oncogenic poten-

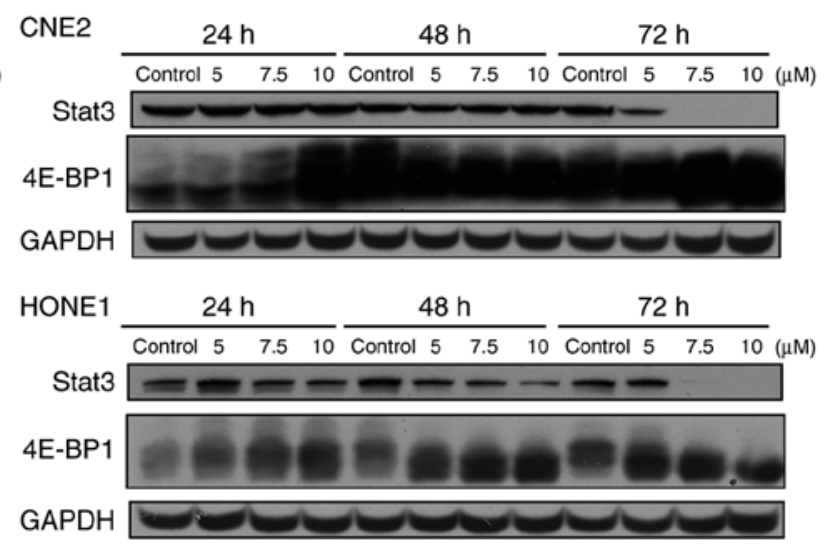

Figure 9. Effects of garcinone $\mathrm{C}$ on expression levels of Stat 3 and 4E-BP1 in CNE1, CNE2, HK1 and HONE1 cells. Cells were treated with 5, 7.5 and $10 \mu \mathrm{M}$ of garcinone $\mathrm{C}$ or 1/2,000 DMSO (control) for 24, 48 and $72 \mathrm{~h}$. At the end of treatments, total cell lysates were prepared and subjected to SDS-PAGE followed by western blot analysis. Membranes were probed with anti-Stat3, 4E-BP1 and GAPDH. GAPDH was used as a loading control. The experiment was repeated three times with similar results. 
tial $(22,23)$. In this study, we found that garcinone $\mathrm{C}$ did not affect the expression level of Stat5, but significantly inhibited the expression of Stat 3 in four NPC cell lines, in a time- and dose-dependent manner. Thus, our findings suggested that garcinone $\mathrm{C}$ inhibits NPC cell growth through a mechanism that likely involves Stat3 inhibition.

The eukaryotic translation initiation factor 4E (elF4E)binding protein 1 (4E-BP1), a translation repressor protein, contributes to the inhibition of protein synthesis and growth inhibition of tumor cells (24). Consistent with our results, it has been reported that some natural compounds could enhance the expression of 4E-BP1 and trigger tumor cell death (25). 4E-BP1 is also regulated by $\mathrm{AKT} / \mathrm{GSK}-3 \beta / \mathrm{AMPK} \alpha / \mathrm{mTOR}$ signaling pathways (26). However, our western blot results showed that although garcinone $\mathrm{C}$ upregulated the expression of 4E-BP1, there was no effect on the expression level of AKT, GSK-3 $\beta$, AMPK $\alpha$, or mTOR, which suggested that garcinone $\mathrm{C}$ might target 4E-BP1 via an AKT/GSK-3 $\beta / \mathrm{AMPK} \alpha / \mathrm{mTOR}$-independent pathway.

In conclusion, garcinone $\mathrm{C}$ treatment was able to decrease the cell viability and colony-formation ability in CNE1 (well-differentiated squamous cell carcinoma), CNE2 (non-keratinizing carcinoma), HK1 (well-differentiated squamous cell carcinoma) and HONE1 (undifferentiated carcinoma) NPC cells. Furthermore, garcinone $\mathrm{C}$ was able to induce $S$ phase cell cycle arrest in all NPC cell lines, and downregulate the expression levels of cell cycle-related proteins cyclin B1, cyclin D1, cyclin E2, cdc2 and CDK7, presumably through ATR activation. Our findings also demonstrated that garcinone $\mathrm{C}$ decreased the expression level of Stat 3 and increased the expression level of 4E-BP1. Moreover, a high-dose of garcinone $\mathrm{C}$ induced necrosis in NPC cells. Taken together, these results revealed that the potential use of garcinone $\mathrm{C}$ as a chemotherapeutic agent in NPC warrants further investigation.

\section{Acknowledgements}

This study was supported by grants from the National Natural Science Foundation of China Key Project 81130046 (to J.Z.), NSFC81171993 (to Yi Lu), NSFC81272415 (to Yi Lu), NSFC81660606 (to X.L.), and NSFC81460397 (to X.L.); China Postdoctoral Science Foundation 2014M552535XB (to X.L.); Guangxi Key Projects 2013GXNSFEA053004 (to J.Z.); Natural Science Foundation of Guangxi 1355004-5 (to J.Z.), 2012 GXNSFCB053004 (to Yi Lu), 2014GXNSFBA118155 (to X.L.), and 2015GXNSFAA139151 (to X.L.); Guangxi Ministry of Education 201202ZD022 (to Yi Lu) and $201201 Z$ D004 (to J.Z.).

\section{References}

1. Zou M, Zhang X and Xu C: IL6-induced metastasis modulators p-STAT3, MMP-2 and MMP-9 are targets of 3,3'-diindolylmethane in ovarian cancer cells. Cell Oncol (Dordr) 39: 47-57, 2016.

2. Guigay J, Temam S, Bourhis J, Pignon JP and Armand JP: Nasopharyngeal carcinoma and therapeutic management: The place of chemotherapy. Ann Oncol 17 (Suppl 10): x304-x307, 2006

3. Shanmugaratnam K: Histological typing of nasopharyngeal carcinoma. IARC Sci Publ: 3-12, 1978.

4. Liu X, Gao Y, Lu Y, Zhang J, Li L and Yin F: Downregulation of NEK11 is associated with drug resistance in ovarian cancer. Int J Oncol 45: 1266-1274, 2014.
5. Wang L, Kuang L, Pan X, Liu J, Wang Q, Du B, Li D, Luo J, Liu M, Hou A and Qian M: Isoalvaxanthone inhibits colon cancer cell proliferation, migration and invasion through inactivating Rac1 and AP-1. Int J Cancer 127: 1220-1229, 2010.

6. Aisha AF, Abu-Salah KM, Ismail Z and Majid AM: In vitro and in vivo anti-colon cancer effects of Garcinia mangostana xanthones extract. BMC Complement Altern Med 12: 104, 2012.

7. Panda SS, Chand M, Sakhuja R and Jain SC: Xanthones as potential antioxidants. Curr Med Chem 20: 4481-4507, 2013.

8. Yi T, Yi Z, Cho SG, Luo J, Pandey MK, Aggarwal BB and Liu M: Gambogic acid inhibits angiogenesis and prostate tumor growth by suppressing vascular endothelial growth factor receptor 2 signaling. Cancer Res 68: 1843-1850, 2008.

9. Rong JJ, Hu R, Song XM, Ha J, Lu N, Qi Q, Tao L, You QD and Guo QL: Gambogic acid triggers DNA damage signaling that induces p53/p21 waf1/CIP1 activation through the ATR-Chk1 pathway. Cancer Lett 296: 55-64, 2010.

10. Wang X and Chen W: Gambogic acid is a novel anti-cancer agent that inhibits cell proliferation, angiogenesis and metastasis. Anticancer Agents Med Chem 12: 994-1000, 2012.

11. Shi X, Chen X, Li X, Lan X, Zhao C, Liu S, Huang H, Liu N, Liao S, Song W, et al: Gambogic acid induces apoptosis in imatinib-resistant chronic myeloid leukemia cells via inducing proteasome inhibition and caspase-dependent Bcr-Abl downregulation. Clin Cancer Res 20: 151-163, 2014.

12. Zhang H,Lei Y, Yuan P,Li L, Luo C, Gao R, Tian J, Feng Z, Nice EC and Sun J: ROS-mediated autophagy induced by dysregulation of lipid metabolism plays a protective role in colorectal cancer cells treated with gambogic acid. PLoS One 9: e96418, 2014.

13. Shibata MA, Iinuma M, Morimoto J, Kurose H, Akamatsu K, Okuno Y, Akao Y and Otsuki Y: $\alpha$-Mangostin extracted from the pericarp of the mangosteen (Garcinia mangostana Linn) reduces tumor growth and lymph node metastasis in an immunocompetent xenograft model of metastatic mammary cancer carrying a p53 mutation. BMC Med 9: 69, 2011.

14. Jittiporn K, Suwanpradid J, Patel C, Rojas M, Thirawarapan S, Moongkarndi P, Suvitayavat W and Caldwell RB: Anti-angiogenic actions of the mangosteen polyphenolic xanthone derivative $\alpha$-mangostin. Microvasc Res 93: 72-79, 2014.

15. Lei J, Huo X, Duan W, Xu Q, Li R, Ma J, Li X, Han L, Li W, Sun $\mathrm{H}$, et al: $\alpha$-Mangostin inhibits hypoxia-driven ROS-induced PSC activation and pancreatic cancer cell invasion. Cancer Lett 347: 129-138, 2014

16. Li P, Tian W and Ma X: Alpha-mangostin inhibits intracellular fatty acid synthase and induces apoptosis in breast cancer cells. Mol Cancer 13: 138, 2014.

17. Fu M, Qiu SX, Xu Y, Wu J, Chen Y, Yu Y and Xiao G: A new xanthone from the pericarp of Garcinia mangostana. Nat Prod Commun 8: 1733-1734, 2013.

18. Poon RY: DNA damage checkpoints in nasopharyngeal carcinoma. Oral Oncol 50: 339-344, 2014

19. Johnson SW, Ozols RF and Hamilton TC: Mechanisms of drug resistance in ovarian cancer. Cancer 71 (2 Supp1): S644-S649, 1993.

20. Sancar A, Lindsey-Boltz LA, Unsal-Kacmaz K and Linn S: Molecular mechanisms of mammalian DNA repair and the DNA damage checkpoints. Annu Rev Biochem 73: 39-85, 2004.

21. Fink SL and Cookson BT: Apoptosis, pyroptosis, and necrosis: Mechanistic description of dead and dying eukaryotic cells. Infect Immun 73: 1907-1916, 2005.

22. Bromberg JF, Wrzeszczynska MH, Devgan G, Zhao Y, Pestell RG, Albanese C and Darnell JE Jr: Stat 3 as an oncogene. Cell 98: 295-303, 1999.

23. Liao Q, Zeng Z, Guo X, Li X, Wei F, Zhang W, Li X, Chen P, Liang F, Xiang B, et al: LPLUNC1 suppresses IL-6-induced nasopharyngeal carcinoma cell proliferation via inhibiting the Stat3 activation. Oncogene 33: 2098-2109, 2014.

24. Constantinou C, Elia A and Clemens MJ: Activation of p53 stimulates proteasome-dependent truncation of eIF4E-binding protein 1 (4E-BP1). Biol Cell 100: 279-289, 2008.

25. Chakravarthy R, Clemens MJ, Pirianov G, Perdios N, Mudan S, Cartwright JE and Elia A: Role of the eIF4E binding protein 4E-BP1 in regulation of the sensitivity of human pancreatic cancer cells to TRAIL and celastrol-induced apoptosis. Biol Cell 105: 414-429, 2013

26. Ma BB, Lui VW, Hui CW, Lau CP, Wong CH, Hui EP, $\mathrm{Ng} \mathrm{MH}$, Tsao SW, Li Y and Chan AT: Preclinical evaluation of the AKT inhibitor MK-2206 in nasopharyngeal carcinoma cell lines. Invest New Drugs 31: 567-575, 2013. 